\title{
KONSEKUENSI HUKUM BAGI INDONESIA TENTANG PENGENDALIAN PENCEMARAN ASAP LINTAS BATAS PASCA RATIFIKASI ASEAN AGREEMENT ON TRANSBOUNDARY HAZE POLLUTION
}

\author{
Agis Ardhiansyah \\ Fakultas Hukum Universitas Brawijaya \\ e-mail: agisardhi@yahoo.co.id
}

\begin{abstract}
ABSTRAK
Jurnal ini bertujuan untuk menganalisis konsekuensi hukum bagi Indonesia tentang pengendalian kabut asap pasca ratifikasi ASEAN Agreement on Transboundary Haze Pollution serta langkah-langkah yang harus dilakukan sebagai wujud asas itikad baik. Jenis penelitian yang digunakan dalam tulisan ini adalah penelitian hukum normatif dengan menggunakan pendekatan aturan hukum tertulis (statute approach). Hasil penelitian yang diperoleh yaitu Indonesia wajib mengambil tindakan di bidang legislatif, administratif serta tindakan teknis lain untuk mencegah kebakaran lahan dan hutannya supaya tidak menimbulkan pencemaran asap wilayah negara lain serta sebagai perwujudan asas itikad baik, Indonesia wajib mengambil langkah prioritas berupa penegakan hukum terhadap pelaku pembakar lahan dan hutan yang menyebabkan kabut asap.

Kata Kunci: Pencemaran asap lintas batas, ASEAN Agreement on Transboundary Haze Pollution, ratifikasi.
\end{abstract}

\section{ABSTRACT}

This journal aims to analyze the legal consequences for Indonesia on preventing and monitoring transboundary haze pollution after the ratification of ASEAN Agreement on Transboundary Haze Pollution and actions that should be taken by the Republic of Indonesia as a form of principle of good faith. This study is a normative legal research by using regulation of written law approach (statute approach). The result of this journal showed that Indonesia shall take legislative, administrative and other steps, as aprinciple of good faith, to prevent, control and mitigate land and forest fires that leads to trans boundary haze pollution. Indonesia also shall enforce the law as a main priority against the person or corporation that burns land and forest.

Keywords: Transboundary haze pollution, ASEAN Agreement on Transboundary Haze Pollution, ratification.

\section{PENDAHULUAN}

Hampir di setiap tahun, memasuki musim kemarau, kebakaran hutan dan lahan kembali terjadi di Indonesia. Pulau Sumatera dan Pulau Kalimantan selalu menjadi langganan kebakaran hutan dan lahan, meskipun di wilayah lain juga terjadi hal serupa seperti di Pulau Sulawesi dan Jawa tetapi dalam skala yang relatif kecil. Berdasarkan pemantauan sejumlah titik api atau hot spot mulai 1 Januari sampai dengan 31 Agustus 2014 di wilayah Pulau Kalimantan, Pulau Sumatera, dan Pulau Sulawesi terdapat hot spot sebanyak 15.300 titik. Data terbaru berdasarkan pemantauan Satelit Terra dan Aqua dari BMKG pada Minggu, 12 Oktober 2014 pukul 05.00 WIB menunjukkan bahwa terdapat 153 hot spot yang masih aktif membakar hutan dan lahan di Sumatera. ${ }^{1}$ Kebakaran hutan dan lahan di beberapa wilayah tersebut menimbulkan kabut asap yang menganggu aktivitas dan kesehatan masyarakat

\footnotetext{
${ }^{1}$ Badan Nasional Penanggulangan Bencana, Data Sebaran Titik Panas Nusantara rentang bulan Januari-Oktober 2014, http://geospasial.bnpb.go.id/monitoring/hotspot/ diakses 10 Maret 2015 pukul 17.00 WIB.
} 
bahkan dampaknya sampai mencemari wilayah negara tetangga, seperti Malaysia, Singapura dan Brunei Darussalam. Akibatnya, pada tahun 2013, Malaysia dan Singapura mengajukan nota protes kepada Pemerintah Indonesia karena kabut asap yang berasal dari Indonesia yang telah mencemari wilayah udaranya dan menyebabkan terganggunya jadwal penerbangan serta terhambatnya aktivitas warga negaranya. Meskipun demikian, kebakaran pada tahun 2014 tidak sampai melintasi batas negara Indonesia. Kecepatan angin tenggara menuju barat, barat laut, dan utara terpantau dengan kecepatan 0515 knot sehingga tidak sampai melintas batas negara tetangga yang kerap menerima asap dari Indonesia, seperti Singapura dan Malaysia. ${ }^{2}$

Sebagai suatu bentuk pencemaran lingkungan yang bersifat transnasional, selain memberikan dampak terhadap kesehatan dan kelayakan ekosistem udara pada tingkat lokal dan nasional, kabut asap yang dihasilkan dari kebakaran/pembakaran hutan/lahan di Indonesia juga telah berdampak pada kelangsungan hidup dan kegiatan ekonomi pada sebagian negara lain dalam lingkup regional ASEAN.

Kabut asap yang hampir tiap tahun terjadi di wilayah Indonesia memunculkan kekhawatiran bagi negara-negara di Asia Tenggara khususnya negaranegara yang berbatasan dengan wilayah Indonesia bahwa asap yang berasal dari Indonesia akan mencemari wilayahnya. Maka tidak mengherankan jika hampir di setiap penyelenggaraan Konferensi Tingkat Tinggi ASEAN (KTT ASEAN), Indonesia selalu "disindir" untuk segera menunjukkan komitmennya dalam pencegahan dan penanggulangan kabut asap yang berasal dari wilayahnya yaitu dengan meratifikasi ASEAN Agreement on Transboundary Haze Pollution (yang selanjutnya disebut AATHP) mengingat sampai dengan tahun 2014 Indonesia merupakan satu-satunya negara anggota ASEAN yang belum meratifikasi perjanjian tersebut. ${ }^{3}$ Menurut pandangan negara-negara regional ASEAN, Indonesia kerap kali dianggap kurang memiliki kepedulian terhadap pengendalian kebakaran hutan/lahan serta masalah asap lintas batas karena belum meratifikasi AATHP. Padahal, Indonesia justru menjadi pihak yang

\section{${ }^{2}$ Ibid.}

${ }^{3}$ Anonim, Indonesia Siap Ratifikasi Perjanjian Asap, http:// www.tempo.co/read/news/2013/07/18/118497386/IndonesiaSiap-Ratifikasi-Perjanjian-Asap (diakses 27 Maret 2015 pukul 08.00 WIB). paling menderita, baik secara ekologis, ekonomis, maupun politis bila kebakaran hutan dan lahan tidak ditangani secara serius. Kondisi ini juga cukup ironis jika kita melihat latar belakang atau aspek filosofis lahirnya AATHP dikarenakan adanya pencemaran udara/kabut asap yang berasal dari Indonesia. Berawal dari fenomena kebakaran hutan yang hebat melanda kawasan ASEAN pada 1997/1998, para petinggi ASEAN mencoba merumuskan pola penanganan yang efektif dengan mengadakan pertemuan persiapan di Hanoi yang menghasilkan Plan of Action and Visi ASEAN 2020. Sebagai puncak pertemuan tersebut, para pemimpin ASEAN merumuskan pola pengendalian pencemaran kabut asap di Asia Tenggara dalam suatu perjanjian yaitu AATHP (Persetujuan ASEAN tentang Pencemaran Asap Lintas Batas) yang mengatur pendistribusian tanggung jawab dan penanganan pencemaran kabut asap di kawasan regional Asia Tenggara. Perjanjian ini ditandatangani oleh 10 negara peserta ASEAN termasuk Indonesia pada Juni 2002 dan berlaku secara efektif pada 25 Nopember $2003 .{ }^{4}$

Berkaitan dengan upaya pengendalian kabut asap, sebenarnya pemerintah Indonesia telah memulainya sejak lama, setidaknya upaya itu telah dimulai sejak tahun 1995. Bahkan melalui Undang-Undang Nomor 18 Tahun 2004 tentang Perkebunan terdapat larangan membuka lahan dengan cara pembakaran pada Pasal 26 jo Undang-Undang Nomor 19 Tahun 2004 tentang Kehutanan, tetapi kenyataannya terlalu sulit untuk menghilangkan kebiasaan masyarakat kita untuk membuka lahan dengan cara pembakaran. Kebanyakan masyarakat kita percaya dengan membakar lahan akan meningkatkan pH (tingkat keasaman) tanah sehingga tanah akan menjadi lebih subur dan cocok untuk bercocok tanam, cara ini juga dinilai lebih murah dan praktis untuk membuka lahan baru. Aturan hukum di Indonesia dinilai masih terlalu lemah bahkan terdapat celah untuk dimanfaatkan oleh oknum-oknum tertentu untuk melakukan pelanggaran hukum. Salah satu contohnya adalah Undang-Undang Nomor 32 Tahun 2009 tentang Perlindungan dan Pengelolaan Lingkungan Hidup Pasal 69 ayat (2) menegaskan bahwa masyarakat diperbolehkan membuka lahan dengan cara membakar untuk luas lahan maksimal 2 hektar per kepala keluarga. Sehingga tidak mengherankan jika musim bercocok tanam tiba akan banyak muncul titik api di beberapa

${ }^{4}$ Ibid. 
daerah di Indonesia, khususnya di Sumatera dan Kalimantan. Sebagai buktinya berdasarkan data dari Badan Nasional Penanggulangan Bencana (yang selanjutnya disebut BNPB) pada bulan Oktober 2015 terdapat 6 Propinsi yang dilanda kebakaran hutan dan lahan, diantaranya adalah Riau (21 titik api), Jambi (105), Sumatera Selatan (571), Kalimantan Barat (508), Kalimantan Tengah (578), dan Kalimantan Selatan (127 titik api). ${ }^{5}$

Komitmen Indonesia dalam hal pengendalian kabut asap lintas batas negara sebenarnya telah dimulai sejak tahun 2008 dengan mengajukan Rancangan Undang-Undang Pengesahan AATHP, tetapi pada waktu itu tidak disetujui oleh DPR. Kemudian Pemerintah Indonesia mengajukan kembali Rancangan Undang-Undang tentang pengesahan AATHP dan dibahas melalui Komisi VII DPR-RI pada tanggal 29 Januari 2014. Pada saaat itu Pemerintah diwakili oleh Menteri Lingkungan Hidup, Prof. Dr. Balthasar Kambuaya, Wakil Menteri Luar Negeri, Wardana, Ketua Dewan Nasional Perubahan Iklim, Ir. Rachmat Witoelar serta perwakilan dari Dirjen Perundang-undangan Kementerian Hukum dan HAM. ${ }^{6}$ Pada tanggal 14 Oktober 2014 Pemerintah Indonesia mengesahkan Undang-Undang Nomor 26 Tahun 2014 tentang Pengesahan AATHP dan instrumen ratifikasinya (instrument of ratification) didepositkan ke Sekretariat ASEAN pada tanggal 20 Januari 2015 sehingga berdasarkan ketentuan perjanjian tersebut (Pasal 29), terhitung sejak 21 Maret 2015, AATHP berlaku efektif (mengikat) bagi Indonesia. Pasca ratifikasi AATHP, desakan untuk segera menyelesaikan permasalahan kabut asap tidak lagi menjadi domain publik dalam negeri saja tetapi juga dari negara lain karena ada kewajiban yang dibebankan kepada Indonesia sebagai bentuk konsekuensi hukum setelah Indonesia meratifikasi AATHP.

\footnotetext{
${ }^{5}$ Anonim, BNPB: Kebakaran Hutan dan Lahan Masih Terjadi di 6 Provinsi, http://waspada.co.id/warta/bnpb-kebakaran-hutandan-lahan-masih-terjadi-di-6-provinsi/, diakses 15 Oktober 2015 pukul 14.20 WIB.

${ }^{6}$ Anonim, Indonesia Meratifikasi Undang-Undang tentang Pengesahan ASEAN Agreement on Transboundary Haze Pollution (Persetujuan Asean tentang Pencemaran Asap Lintas Batas), http://www.menlh.go.id/indonesia-meratifikasi-undang-undangtentang-pengesahan-asean-agreement-on-transboundary-hazepollution-persetujuan-asean-tentang-pencemaran-asap-lintasbatas/, diakses 20 Maret 2015 pukul 17.15 WIB.
}

Tanggung jawab Pemerintah Indonesia terkait pengendalian kabut asap tidak hanya kepada publik dalam negeri saja tetapi juga kepada negara lain terutama Negara Peserta AATHP sebagai bukti pelaksanaan asas itikad baik atau good faith. Setiap negara yang meratifikasi suatu perjanjian internasional tujuan utamanya pasti demi kepentingan nasional, dalam artian negara peratifikasi/aksesor tersebut telah mempertimbangkan dengan sungguhsungguh konsekuensi dari pengikatan dirinya atau consent to be bound pada suatu perjanjian internasional sehingga kepentingan nasionalnya tidak akan dirugikan meskipun ada beban kewajiban dari perjanjian tersebut. Untuk itulah langkahlangkah internal atau domestic maupun eksternal atau international harus segera dipersiapkan dan dilaksanakan oleh Pemerintah Indonesia agar tidak terjadi pelanggaran dalam perjanjian atau breach of contract, karena perjanjian tersebut telah mengikat kita secara internasional atau pacta sunt servanda tanpa merugikan kepentingan nasional kita. Tulisan ini menggunakan metode normatif dengan pendekatan peraturan tertulis atau statute approach.

\section{PEMBAHASAN \\ Konsekuensi Hukum Bagi Indonesia terkait dengan Pengendalian Pencemaran Asap Lintas Batas Pasca Ratifikasi AATHP}

Setiap perjanjian akan berlaku dan mengikat para pihak pesertanya saat syarat-syarat sahnya perjanjian tersebut terpenuhi, tidak terkecuali juga untuk perjanjian internasional. Keterikatan subyek hukum internasional kepada suatu perjanjian internasional, sebagaimana telah ditentukan oleh Pasal 11 Konvensi Wina 1969, ditentukan oleh perjanjian itu sendiri, bisa melalui penandatanganan (signature), pertukaran instrument yang membentuk perjanjian (exchange of instruments constituting a treaty), ratifikasi (ratification), penerimaan (acceptance), persetujuan (approval) dan aksesi (accession). ${ }^{7}$ Jika perjanjian tersebut mempersyaratkan untuk diratifikasi maka pada tahap penandatanganan, perjanjian tersebut belum mengikat pesertanya. Agar berlaku mengikat maka peserta perjanjian wajib menyerahkan piagam pengesahan (instrument of ratification) dan saling ditukarkan antar peserta perjanjian sebagai bentuk pemenuhan persyaratan sahnya perjanjian.

\footnotetext{
${ }^{7}$ I Wayan Parthiana, Hukum Perjanjian Internasional Bagian 1, Mandar Maju, Bandung, 2002, h. 109.
} 
Dengan penyerahan dan pertukaran instrument of ratification belum tentu perjanjian tersebut langsung berlaku secara efektif (entry into force) karena pada umumnya setiap perjanjian yang mempersyaratkan ratifikasi membutuhkan jumlah minimal negara yang meratifikasi (lebih dari dua negara) dan jangka waktu berlakunya yang terhitung sejak pendepositan instrument of ratification.

Untuk praktek Indonesia, prosedur ratifikasi perjanjian internasional dapat dibedakan menjadi dua macam, yaitu secara internal dan eksternal. Ratifikasi secara internal dilakukan melalui Undang-Undang dan Peraturan Presiden, tergantung materi perjanjian internasional. Sedangkan ratifikasi eksternal dilakukan dengan menerbitkan instrument of ratification atau instrument of accession. Ratifikasi secara internal tidak menimbulkan konsekuensi keterikatan Indonesia pada suatu perjanjian internasional, tetapi hanya melalui ratifikasi eksternal-lah suatu negara akan terikat pada suatu perjanjian internasional. Alasannya adalah ratifikasi internal merupakan prosedur yang diatur berdasarkan hukum nasional, yang mana itu merupakan urusan domestik suatu negara. Berbeda halnya dengan ratifikasi eksternal yang memang diatur oleh hukum internasional. Jika mengkaji unsur perjanjian internasional dimana salah satunya adalah harus tunduk dan patuh pada hukum internasional maka jelas bahwa mekanisme yurisdiksi suatu negara terkait pengesahan perjanjian internasional tidak akan memberikan konsekuensi hukum apapun terkait keterikatan pada perjanjian internasional.

Penyerahan piagam pengesahan atau instrument of ratification merupakan bentuk pernyataan tegas dari negara untuk terikat pada pejanjian internasional. Sebagai negara yang berdaulat, dia tidak bisa dipaksa oleh kekuatan apapun untuk menerima sesuatu yang tidak dikehendakinya, seperti menyatakan terikat pada suatu perjanjian internasional. Dengan demikian, instrument of ratification merupakan manifestasi dari kedaulatan negara untuk terikat pada perjanjian internasional.

Setiap perjanjian internasional yang telah diratifikasi dan memenuhi syarat berlaku secara efektif maka sejak itu pula perjanjian tersebut akan mengikat negara peserta. Dengan demikian segala konsekuensi hukum yang terkandung di dalamnya seperti hak dan kewajiban peserta akan dibebankan kepadanya. Secara moral, setiap negara dalam menyusun dan melaksanakan perjanjian internasional akan selalu terikat pada ketiga asas dasar yaitu kebebasan bersepakat atau free consent, itikad baik atau good faith dan kesepakatan mengikat para pihak atau pacta sunt servanda. Ketiga asas tersebut bersifat imperatif (memaksa) dan harus dipatuhi meskipun tidak tertulis dalam naskah perjanjian karena ketiganya termasuk dalam asas dasar atau ius cogens dalam hukum perjanjian internasional. Setiap bentuk pelanggaran hak peserta perjanjian dan kegagalan dalam pemenuhan kewajiban akan menimbulkan konsekuensi hukum bagi negara peserta atau contracting state. ${ }^{8}$

Keikutsertaan suatu negara dalam perjanjian internasional tentu saja didasarkan atas kepentingan nasionalnya, yang artinya dengan ikut serta dalam perjanjian internasional, negara menganggap akan menguntungkan kepentingan nasionalnya. Tidak logis jika ada suatu negara rela terikat oleh suatu perjanjian internasional dengan segala konsekuensi yang terkandung didalamnya padahal diketahui bahwa akan merugikan kepentingan nasionalnya. Sehingga dapat diperkirakan bahwa negara yang menjadi peserta suatu perjanjian internasional, sebelum menyatakan keterikatannya, sudah menjadi keharusan untuk mempertimbangkan dengan sungguh-sungguh untung dan ruginya, karena tidaklah mudah bagi negara yang telah menjadi peserta perjanjian untuk keluar dari perjanjian yang telah disepakati bersama.

Setiap perjanjian internasional yang dibuat oleh subyek hukum internasional memiliki maksud dan tujuan yang dituangkan dalam bagian pembukaan atau preambule. Bagian pembukaan atau preambule perjanjian internasional pada umumnya memuat memuat tiga unsur, yaitu unsur filosofis (latar belakang dibuatnya perjanjian), unsur yuridis (asas hukum rasional atau ius dispositivum) dan unsur politis (tujuan yang ingin dicapai dari perjanjian). ${ }^{9}$

AATHP 2002 yang disahkan dengan UndangUndang Nomor 26 Tahun 2014 dan instrument of ratification-nya telah didepositkan ke Sekretariat ASEAN pada tanggal 20 Januari 2015 sehingga berdasarkan ketentuan perjanjian tersebut (Pasal 29),

\footnotetext{
${ }^{8}$ Ulf Linderfalk, On the Interpretation of Treaties: The Modern International Law as Expressed in the 1969 Vienna Convention on the Law of Treaties, Springer, Dordrecht, Netherlands, 2007, h. 67.

${ }^{9}$ Jan Klabbers, The Concept of Treaty in International Law Vol. 22, Kluwer Law International, Dordrecht, Netherlands, 1998, h. 37.
} 
terhitung sejak 21 Maret 2015, AATHP berlaku efektif (mengikat) bagi Indonesia. Jika memperhatikan bagian pembukaan AATHP terlihat bahwa perjanjian ini masih membawa semangat dibentuknya ASEAN, yaitu peningkatan kerjasama, kemitraan dan kebersamaan untuk mencapai perdamaian, kemajuan dan kesejahteraan di kawasan Asia Tenggara. Pembentukan persetujuan atau agreement tersebut dilatarbelakangi adanya pencemaran udara lintas batas yang terjadi di kawasan Asia Tenggara yang berpotensi menimbulkan akibat yang merugikan bagi negara-negara. Tujuannya adalah untuk lebih memperkuat kerjasama internasional dalam mengembangkan kebijakan nasional dalam pencegahan dan pemantauan pencemaran asap lintas batas, koordinasi aksi nasional untuk pencegahan dan pemantauan pencemaran asap lintas batas melalui pertukaran informasi, konsultasi, penelitian dan pemantauan.

Disamping itu, para pihak berkeinginan untuk mengambil tindakan secara mandiri maupun bersama untuk melakukan penilaian asal, sebab, sifat dan luas dari kebakaran lahan dan hutan serta asap yang ditimbulkan, maksudnya adalah untuk mencegah dan mengendalikan sumber kebakaran lahan dan hutan serta asap yang ditimbulkannya dengan menerapkan kebijakan praktek dan teknologi berwawasan lingkungan serta memperkuat kemampuan nasional dan regional dan juga untuk menjalin kerjasama dalam penilaian, pencegahan, penanggulangan dan pengelolaan kebakaran lahan dan hutan serta asap yang ditimbulkan.

Adapun 5 (lima) prinsip yang terkandung dalam AATHP sekaligus sebagai panduan bagi para pihak peserta perjanjian dalam melaksanakan isi perjanjian, sebagaimana dinyatakan dalam Pasal 3 yaitu:

Pertama, hak berdaulat untuk mengeksploitasi sumber dayanya sesuai kebijakan lingkungan dan pembangunannya, dan tanggung jawab untuk menjamin bahwa kegiatan dalam yurisdiksi dan kendalinya tidak menyebabkan kerusakan pada lingkungan dan membahayakan kesehatan manusia dari negara lain atau daerah di luar batas yurisdiksi nasional.

Kedua, semangat kesetiakawanan dan kemitraan dan sesuai dengan kebutuhan, kemampuan dan situasi masing-masing, memperkuat kerjasama dan koordinasi untuk mencegah dan memantau pencemaran asap lintas batas sebagai akibat dari kebakaran lahan dan/atau hutan yang harus ditanggulangi.

Ketiga, mengambil tindakan berhati-hati untuk mengantisipasi, mencegah dan memantau pencemaran asap lintas batas sebagai akibat dari kebakaran lahan dan/atau hutan yang seharusnya ditanggulangi, untuk meminimalkan pengaruh yang merugikannya. Apabila terjadi ancaman serius atau kerusakan yang tidak dapat diperbaiki dari pencemaran asap lintas batas, walaupun tanpa kepastian ilmiah yang penuh, tindakan berhati-hati akan diambil oleh pihak yang bersangkutan.

Keempat, mengelola dan memanfaatkan sumber daya alam, termasuk sumber daya hutan dan lahan, dengan cara berkelanjutan dan berwawasan ekologi.

Kelima, dalam mengatasi pencemaran asap lintas batas, jika dipandang perlu, melibatkan semua pihak terkait, termasuk masyarakat lokal, lembaga swadaya masyarakat, petani dan perusahaan swasta.

Selain kelima prinsip tersebut, AATHP juga membebankan 3 (tiga) kewajiban umum bagi para pihak peserta, sebagaimana dinyatakan dalam Pasal 4, diantaranya:

Pertama, bekerjasama dalam mengembangkan dan melaksanakan tindakan untuk mencegah dan memantau pencemaran asap lintas batas akibat kebakaran lahan dan/atau hutan yang harus ditanggulangi, dan untuk mengendalikan sumber kebakaran, termasuk identifikasi kebakaran, pengembangan pemantauan, penilaian dan sistem peringatan dini, pertukaran informasi dan teknologi, dan ketentuan bantuan yang saling menguntungkan.

Kedua, apabila pencemaran asap lintas batas berasal dari wilayah salah satu negara peserta perjanjian, harus dilakukan respon yang cepat terhadap permintaan informasi yang relevan atau konsultasi yang dibutuhkan oleh negara-negara yang terkena imbas atau berpotensi terkena imbas pencemaran asap lintas batas tersebut, dengan tujuan untuk meminimalkan akibat dari pencemaran asap lintas batas.

Ketiga, Mengambil tindakan legislatif, administratif dan/atau tindakan lainnya untuk melaksanakan kewajiban berdasarkan persetujuan.

Sepintas perjanjian tersebut menunjukkan bahwa terkait dengan pengendalian pencemaran udara lintas batas, diperlukan adanya kerja sama antara anggota ASEAN. Pengendalian pencemaran udara lintas batas yang selama ini terjadi di kawasan Asia Tenggara 
diyakini akan lebih efektif jika dilakukan secara bersama-sama melalui kerjasama internasional. Dengan demikian pembebanan tanggung jawab terkait pengandalian kabut asap lintas batas tidak hanya berada di pihak Indonesia saja tetapi ditanggung secara bersama-sama dengan negara anggota ASEAN yang lain. Latar belakang lahirnya perjanjian ini tidak dapat dipungkiri karena ketidakmampuan Indonesia dalam mengendalikan kabut asap yang berasal dari kebakaran hutan atau lahan yang selama kurun waktu 20 tahun ini dimana hampir tiap tahunnya mencemari wilayah negara tetangga, terutama Malaysia dan Singapura. Tentu saja harapan yang muncul pasca Indonesia meratifikasi AATHP adalah kabut asap yang selama ini melanda Indonesia dan mencemari wilayah udara negara tetangga dapat dicegah dan dikendalikan.

Beberapa upaya dalam pengendalian pencemaran udara lintas batas sebagaimana diamanatkan dalam ketentuan AATHP salah satunya adalah pendirian ASEAN Centre (Pasal 5) sebagai pusat koordinasi ASEAN untuk pengendalian pencemaran asap lintas batas. Tujuan dari pendirian ASEAN Centre untuk memfasilitasi kerjasama dan koordinasi antar negara peserta perjanjian dalam mengelola dampak dari kebakaran lahan dan/atau hutan khususnya pencemaran asap yang timbul dari kebakaran tersebut. ASEAN Centre wajib bekerja atas dasar bahwa lembaga nasional yang berwenang akan bertindak terlebih dahulu untuk memadamkan kebakaran. Apabila lembaga nasional yang berwenang menyatakan suatu keadaan darurat, lembaga tersebut dapat mengajukan permohonan kepada ASEAN Centre untuk memberikan bantuan.

Disamping itu, AATHP juga mengamanatkan pembentukan badan yang disebut dengan Focal Point, yang diberikan wewenang oleh masingmasing negara peserta perjanjian untuk menerima dan menyampaikan komunikasi dan data yang berhubungan dengan ketentuan perjanjian. Selain itu, Para Pihak juga wajib menunjuk satu badan/ lebih di dalam negerinya, yang berfungsi sebagai Pusat Pemantauan Nasional untuk melaksanakan tugas (Pasal 7): Pemantauan daerah rawan kebakaran; Pemantauan terhadap terjadinya kebakaran lahan/ hutan; Pemantauan kondisi lingkungan yang mengakibatkan kebakaran lahan/hutan; Pemantauan terhadap pencemaran asap yang ditimbulkan oleh kebakaran lahan/hutan.
Pada dasarnya Para Pihak memiliki kewajiban untuk mengambil tindakan sebagai upaya pencegahan dan pengendalian yang berkaitan dengan kebakaran lahan/hutan yang berpotensi menimbulkan pencemaran asap lintas batas, sebagaimana dinyatakan dalam Pasal 9, diantaranya: 1. mengembangkan dan melaksanakan tindakan legislatif dan peraturan lainnya, maupun program dan strategi untuk mempromosikan kebijakan pembukaan lahan tanpa bakar sehubungan dengan kebakaran lahan dan/ atau hutan yang mengakibatkan pencemaran asap lintas batas; 2. mengembangkan kebijakan lainnya yang sesuai untuk menghambat aktifitas yang dapat mengakibatkan kebakaran lahan dan/atau hutan; 3. mengidentifikasi dan memantau daerah rawan terhadap terjadinya kebakaran lahan dan/atau hutan; 4. memperkuat pengelolaan kebakaran dan kemampuan memadamkan kebakaran serta koordinasi untuk mencegah terjadinya kebakaran lahan dan/atau hutan di tingkat lokal; 5. mempromosikan pendidikan dan kampanye pembangunan kesadaran masyarakat serta memperkuat peran serta masyarakat dalam pengelolaan kebakaran guna mencegah kebakaran lahan dan/atau hutan serta pencemaran asap yang timbul dari kebakaran tersebut; 6. mempromosikan dan memanfaatkan pengetahuan dan praktek kearifan tradisional dalam pencegahan dan pengelolaan kebakaran; dan 7. menjamin bahwa tindakan legislatif, administratif dan/atau tindakan lainnya yang relevan diambil untuk mengendalikan pembakaran terbuka serta mencegah pembukaan lahan dengan membakar.

Mengacu pada ketentuan Pasal 9 tersebut dapat diketahui bahwa berkaitan dengan permasalahan pencegahan dan pengendalian kebakaran lahan dan hutan lebih mengedepankan melalui mekanisme hukum nasional. Setiap negara peserta AATHP wajib melakukan tindakan legislatif, administratif maupun yudikatif sebagai upaya pencegahan dan penanggulangan kebakaran lahan/hutan. Penegakan hukum terhadap pelaku/perusahaan yang membakar lahan/hutan untuk membuka lahan baru harus dilakukan agar tidak terjadi lagi bencana kabut asap yang yang merugikan rakyat Indonesia maupun negara lain. Sebenarnya kalau dipahami substansi yang termuat dalam AATHP, sebagaimana termuat dalam Pasal 9, merupakan bentuk penghormatan hukum internasional terhadap kedaulatan negara. Oleh karena itu, berdasarkan AATHP yang telah diratifikasi oleh Indonesia terdapat beberapa konsekuensi didalamnya 
sebagai akibat keterikatan, yaitu: 1. Indonesia harus menjamin bahwa semua kegiatan yang ada wilayahnya tidak akan menyebabkan kerusakan lingkungan dan membahayakan kesehatan manusia bagi negara lain atau daerah di luar batas yurisdiksi nasionalnya; 2 . Indonesia wajib bekerjasama dalam mengembangkan dan melaksanakan tindakan untuk mencegah dan memantau pencemaran asap lintas batas akibat kebakaran lahan dan hutan; 3. Indonesia wajib memberikan respon/tanggapan yang cepat terhadap adanya permintaan infomasi yang relevan atau konsultasi yang dibutuhkan oleh negara-negara yang terkena dampak pencemaran asap yang berasal dari Indonesia, dengan tujuan untuk meminimalkan akibat pencemaran.

Tetapi jika melihat pada ketentuan pasal per pasal, dapat diketahui bahwa dengan meratifikasi AATHP tersebut, Indonesia akan mendapatkan banyak keuntungan, seperti: a. Indonesia dapat memanfaatkan sumber daya manusia dan dana yang disediakan dalam AATHP; b. Dari sisi pertanggungjawaban negara atau liability, Indonesia akan terhindar dari adanya potensi gugatan ganti rugi oleh negara tetangga. Hal ini dikarenakan permasalahan kabut asap merupakan tanggung jawab seluruh negara anggota AATHP dan bukannya masalah satu negara saja. Segala potensi yang ada di negara anggota ASEAN, termasuk dana yang dialokasikan dapat dimanfaatkan untuk menyelesaikan permasalahan kabut asap; c. Indonesia akan memiliki anggaran yang terkumpul dari berbagai sumber yang dapat digunakan untuk mengatasi kebakaran hutan dan lahan. Tanpa meratifikasi pun kita juga akan mengeluarkan dana untuk memadamkan kebakaran, namun dengan meratifikasi maka dana yang bisa digunakan akan menjadi lebih besar. Dengan AATHP, pengendalian kebakaran dapat dilaksanakan secara bersama-sama dengan negara ASEAN lainnya.

\section{Langkah-langkah yang Harus Dilakukan oleh Pemerintah Indonesia sebagai Wujud Pelaksanaan Asas Itikad Baik terkait Pengendalian Pencemaran Asap Lintas Batas Pasca Ratifikasi AATHP}

Dalam proses pembuatan maupun pelaksanaan perjanjian terdapat satu asas (dari tiga asas) yang bersifat fundamental atau ius cogens yaitu asas itikad baik atau good faith. Asas ini menekankan bahwa para pihak yang terlibat dalam proses dan dalam tahapan pelaksanaan perjanjian harus mengedepankan itikad baik agar kesepakatan yang dicapai dapat dijalankan dengan baik dan tidak merugikan peserta perjanjian yang lain. Memang tidaklah mudah untuk mengetahui apakah peserta perjanjian beritikad baik tetapi setidaknya penerapan asas ini bisa diukur dari perbuatan para peserta perjanjian dalam melaksanakan ketentuan perjanjian yang telah disepakati bersama. ${ }^{10}$ Semakin terlihat upaya peserta perjanjian dalam melaksakan kewajibannya sesuai dengan isi perjanjian maka akan terlihat bahwa peserta perjanjian tersebut memang memiliki itikad yang baik.

Pada dasarnya setiap kesepakatan yang dihasilkan dalam forum ASEAN selalu mengutamakan Non Interference Principle atau prinsip tidak mencampuri urusan dalam negeri negara lain. Menurut Acharya, prinsip non interference atau tidak mencampuri urusan dalam negeri negara lain merupakan salah satu prinsip dalam ASEAN yang tumbuh dan dalam proses evolusi ASEAN sebagai organisasi internasional regional. Prinsip ini secara kuat tercantum dalam dokumen-dokumen ASEAN seperti Treaty Amity and Cooperation 1976 sampai dengan Piagam ASEAN 2007. Prinsip ini telah menjadi landasan bagi ASEAN dalam memelihara hubungan baik antara anggota ASEAN dan terbukti dapat membebaskan kawasan Asia Tenggara dari konflik terbuka sejak ASEAN berdiri. Kuatnya prinsip non interference dalam ASEAN dapat dipahami dari latar belakang sejarah negara-negara Asia Tenggara seperti intervensi kolonial, intervensi militer negara adidaya pada era perang dingin, peselisihan dan konflik internal terutama yang bersumber dari gerakan komunis dan pemisahan diri. Prinsip tidak mencampuri urusan dalam negeri negara lain ini kemudian mendapat ujian bagi relevansinya dalam menghadapi permasalahan kabut asap. Permasalahan kabut asap yang berasal dari kebakaran laham dan hutan di Indonesia mengakibatkan kerugian tidak hanya di Indonesia tetapi meluas sampai ke Singapura, Malaysia dan Brunei Darussalam. Prinsip non interference cenderung menganggap masalah ini sebagai urusan dalam negeri Indonesia. ${ }^{11}$

${ }^{10}$ Eddy Pratomo, Hukum Perjanjian Internasional: Pengertian, Status Hukum dan Ratifikasi, Alumni, Bandung, 2012, h. 67.

${ }^{11}$ Sidiq Ahmadi, "Prinsip Non-Interference ASEAN dan Problem Efektifitas ASEAN Agreement on Transboundary Haze Pollution", Jurnal Media Hukum, Universitas Muhammadiyah Yogyakarta, 2013, h. 187. 
Meskipun dalam AATHP dinyatakan bahwa permasalahan pencemaran udara lintas batas merupakan tanggung jawab bersama dan harus ditangani dengan kerjasama antar negara ASEAN, bukan berarti bahwa AATHP meninggalkan prinsip non interference, tetapi malah sebaliknya yaitu memperkuat prinsip tersebut. Berdasarkan ketentuan Pasal 4 ayat (3) AATHP menegaskan Para Pihak wajib mengambil tindakan legislatif, administratif ataupun tindakan lain untuk mencegah dan mengendalikan kebakaran hutan dan lahan, dimana tindakan-tindakan tersebut merupakan urusan dalam negeri/kewenangan suatu negara. Sehingga jika melihat ketentuan pasal tersebut merupakan bentuk penghormatan kepada kedaulatan negara.

Pengutamaan mekanisme dalam negeri/nasional dalam hal pencegahan dan pengendalian pencemaran udara akibat kebakaran lahan dan hutan sudah sangat tepat dan menguntungkan, khususnya bagi Indonesia. Meskipun selama ini Indonesia selalu menjadi pihak yang dianggap penyebab terjadinya pencemaran udara lintas batas dan dianggap tidak mampu mengatasinya, tetapi tidak dapat dipungkiri bahwa pihak yang paling rugi (menderita) akibat bencana kabut asap tidak lain adalah Indonesia. Data Kementerian Lingkungan Hidup dan Kehutanan RI menyebutkan indikasi areal kebakaran hutan dan lahan per 9 September 2015 di Kalimantan dan Sumatera seluas 190.993 hektar. Luasan tersebut terdiri dari 103.953 hektar di lahan pemanfaatan, 29.437 hektar di lahan perkebunan pelepasan, dan 58.603 hektar di lahan bidang tanah Badan Pertanahan Nasional (BPN). Badan Nasional Penanggulangan Bencana (BNPB) memprediksi kerugian ekonomi akibat bencana kabut asap yang terjadi karena kebakaran hutan dan lahan di beberapa Propinsi di Indonesia pada 2015 bisa melebihi angka 20 trilliun rupiah. Berdasarkan data Kementerian Kesehatan RI, 99 persen penyebab kebakaran hutan dan lahan merupakan faktor yang disengaja. Citra satelit yang diambil NASA membuktikan bahwa kebakaran hutan dan lahan yang terjadi di Sumatera merupakan kesengajaan karena areal hutan dan lahan yang dibakar api memiliki pola. Motifnya sangat jelas, membakar lahan dan hutan dinilai sebagai cara paling mudah, murah dan cepat untuk membersihkan lahan atau land clearing meski dampak kerusakannya sangat massif.

Kerugian yang ditimbulkan akibat kebakaran hutan dan lahan seolah-olah seperti tak terhitung nilainya. Ratusan ribu orang menderita Infeksi Saluran Pernafasan Akut (ISPA) dimana sebagian besar adalah anak-anak yang memang rentan terserang ISPA. Bahkan sempat ramai di media sosial Facebook ada bayi perempuan mungil yang usianya belum ada satu tahun dari Hulu Sungai Selatan, Kalimantan Selatan, meninggal karena ISPA yang disebabkan kabut asap akibat pembakaran lahan dan hutan di Kalimantan. ${ }^{12}$ Setidaknya hingga bulan September 2015, bencana kabut asap telah mengakibatkan tiga korban jiwa. Berkaitan dengan upaya penegakan hukum terhadap pelaku dan perusahaan pembakar lahan/hutan sehingga menimbulkan kabut asap, Kepolisian Republik Indonesia hingga September 2015 telah menetapkan 140 tersangka, dimana 7 (tujuh) diantaranya adalah petinggi perusahaan. Mereka disangkakan melakukan pelanggaran ketentuan dalam Undang-Undang Nomor 39 Tahun 2014 tentang Perkebunan dan Undang-Undang Nomor 32 Tahun 2009 tentang Perlindungan dan Pengelolaan Lingkungan Hidup, dengan ancaman penjara selama kurang lebih 10 tahun dan denda sebesar 10 milliar rupiah. Jumlah tersangka pelaku pembakaran lahan dan hutan diperkirakan bertambah karena aparat kepolisian masih memeriksa puluhan perusahaan yang diduga melakukan praktik pembakaran lahan dan hutan. Jika terbukti maka izin konsesi perusahaan terancam akan dicabut dan dibekukan. Data Kementerian Lingkungan Hidup dan Kehutanan beserta Kepolisian RI menyebutkan bahwa ada ratusan kasus kebakaran hutan dan lahan yang terjadi di area konsesi perusahaan di Sumatera dan Kalimantan yang ditangani pada tahun 2015. Di Riau terdapat 37 kasus, Sumatera Selatan 16 kasus, Kalimantan Barat 11 kasus dan Kalimantan Tengah 121 kasus. $^{13}$

Meskipun aparat kepolisian dan dinas terkait telah melakukan berbagai upaya penegakan hukum terhadap pelaku pembakaran dan perusahaan yang diduga terlibat nyatanya bencana kabut asap tetap saja terjadi hampir tiap tahun di musim kemarau. Melihat kondisi ini tidaklah mengherankan jika rakyat kita meragukan komitmen Pemerintah dalam mengendalikan pencemaran udara akibat kebakaran

12 Marison Guciano, Kebakaran Hutan dan Kejahatan Korporasi, http://nasional.kompas.com/read/2015/10/03/16191531/ Kebakaran.Hutan.dan.Kejahatan.Korporasi?page=all, diakses pada 10 Oktober 2015 pukul 14.00 WIB.

${ }^{13} \mathrm{Ibid}$. 
lahan dan hutan. Bahkan banyak yang berpendapat bahwa semua upaya yang telah dilakukan oleh Pemerintah hanyalah upaya setengah hati. Berbagai tawaran dari negara tetangga seperti Malaysia dan Singapura untuk mengirimkan tim dan peralatan guna membantu mengendalikan kabut asap di wilayah Indonesia selalu ditolak oleh Pemerintah RI, alasannya tetap sama, Indonesia masih mampu menanganinya. Padahal jika mengacu pada ketentuan AATHP, yang telah kita ratifikasi pada Januari 2015, Indonesia terikat kewajiban untuk menjamin bahwa setiap kegiatan dalam yurisdiksinya tidak menyebabkan kerusakan pada lingkungan dan membahayakan kesehatan manusia, baik di negaranya sendiri dan juga bagi negara lain. Memang perjanjian ini tidak memuat mekanisme sanksi, seperti ganti rugi, manakala ada salah satu Pihak peserta perjanjian yang tidak menjalankan kewajibannya sebagaimana telah diatur dalam perjanjian tersebut. Tetapi bukan berarti bahwa Indonesia dapat seenaknya melanggar ketentuan perjanjian.

Sebagai negara yang telah meratifikasi AATHP maka Indonesia terikat pada segala ketentuan yang terdapat pada perjanjian tersebut. Konsekuensi hukum atas ratifikasi tersebut tentu adalah penerapan isi perjanjian ke dalam sistem hukum nasional Indonesia, baik itu melalui Undang-Undang, Peraturan Presiden atau pun produk hukum lainnya. Dalam artian lain, produk hukum nasional yang berkaitan dengan permasalahan pengendalian kebakaran hutan dan lahan, substansinya harus selaras dengan ketentuan AATHP. Perlu untuk diketahui bahwa jika suatu negara telah meratifikasi/terikat pada suatu perjanjian internasional maka kedudukan perjanjian internasional tersebut lebih tinggi/lebih diutamakan atau superior dibandingkan dengan hukum nasionalnya atau inferior. Kondisi ini bukan berarti bahwa hukum internasional mendegradasi kedaulatan suatu negara, melainkan sebagai bentuk konsekuensi atas adanya pernyataan keterikatan suatu negara kepada ketentuan hukum internasional atau perjanjian internasional yang diwujudkan melalui instrument of ratification. Keterikatan Indonesia kepada AATHP bukanlah karena suatu paksaan melainkan kesukarelaan, hal ini bisa dilihat dari rentang waktu 14 tahun setelah perjanjian tersebut ditandatangani, dimana selama rentang waktu 14 tahun tersebut Indonesia telah memikirkan segala konsekuensi, untung dan ruginya jika Indonesia terikat pada AATHP. Sehingga dengan pengertian yang lain, melalui pendepositan instrument of ratification dapat diartikan juga Indonesia telah menundukkan kedaulatannya pada ketentuan yang terdapat dalam AATHP.

Asas pacta sund servanda membebani negara yang telah meratifikasi suatu perjanjian internasional untuk melaksanakan isi perjanjian secara penuh atau kecuali ada reservasi. Segala kebijakan yang terkait dengan substansi perjanjian harus dirumuskan selaras dengan maksud dan tujuan perjanjian. Untuk itulah langkahlangkah internal atau domestic policy perlu dilakukan agar tidak memunculkan pertanggungjawaban atau liability secara internasional. Beberapa langkah yang harus dilakukan oleh pemerintah Indonesia sebagai wujud itikad baik atau good faith dalam pelaksanaan ketentuan AATHP untuk mencegah dan mengendalikan kebakaran lahan dan hutan agar tidak menimbulkan pencemaran udara lintas batas yaitu:

Pertama, Bidang Legislatif. Salah satu hal yang paling utama pasca ratifikasi AATHP adalah keselarasan antara ketentuan perjanjian dengan instrumen hukum nasional yang terkait. AATHP mengamanatkan bahwa di bidang legislatif, Para Pihak berkewajiban untuk mengambil tindakan untuk mencegah dan mengendalikan kebakaran hutan dan lahan, dengan arti lain bahwa tidak ada pembenaran dengan alasan apapun terhadap aktivitas pembukaan lahan dengan cara membakar. Kondisi ini bertolak belakang dengan ketentuan yang terdapat pada Pasal 69 UU No. 32 Tahun 2009 tentang Perlindungan dan Pengelolaan Lingkungan Hidup. Pada dasarnya pasal tersebut melarang pembukaan lahan dengan cara membakar tetapi pada ayat (2) larangan tersebut tetap harus memperhatikan kearifan lokal yang ada di setiap daerah. Ketentuan ini diperjelas di bagian penjelasan bahwa dengan memperhatikan kearifan lokal maka pembakaran lahan boleh dilakukan dengan luas lahan maksimal 2 hektar per kepala keluarga untuk ditanami tanaman jenis varietas lokal dan dikelilingi oleh sekat bakar sebagai pencegah penjalaran api ke wilayah sekelilingnya. Persoalannya adalah apabila dalam satu wilayah ada 100 warga, maka sangat dimungkinkan area yang terbakar ada 100 titik, apalagi, makin banyak warga pendatang yang masuk ke daerah pedalaman untuk membuka lahan, baik untuk perkebunan maupun budidaya tanaman pangan. Belum lagi tidak adanya jaminan bahwa pembakaran tersebut akan dipasangi sekat untuk mencegah perluasan area lahan yang dibakar. 
Selain undang-undang lingkungan hidup, ternyata UU No. 41 Tahun 1999 tentang Kehutanan juga masih memperbolehkan untuk membakar hutan, ketentuan ini terdapat pada Pasal 50 ayat (3) huruf d. Penjelasan pasal tersebut adalah pembakaran hutan secara terbatas diperkenankan hanya untuk tujuan khusus atau kondisi yang tidak dapat dielakkan antara lain pengendalian kebakaran hutan, pembasmian hama dan penyakit serta pembinaan habitat tumbuhan dan satwa. Maka dari itu, UU No. 32 Tahun 2009 tentang Perlindungan dan Pengelolaan Lingkungan Hidup dan UU No. 41 Tahun 1999 tentang Kehutanan perlu direvisi agar sesuai dengan amanat AATHP.

Kedua, Bidang Administratif. Pemberian ijin terhadap individu maupun korporasi untuk membuka atau menguasai lahan perlu untuk ditinjau ulang. Dalam era saat ini, pembangunan di setiap negara harus berlandaskan prinsip berkelanjutan atau sustainable development dengan mengedepankan tiga pilar yaitu pilar lingkungan hidup, pilar ekonomi dan pilar sosial. Jadi tidak tepat jika pertimbangan dalam pemberian ijin membuka/penguasaan lahan hanya demi keuntungan ekonomi semata. Pencabutan ijin terutama kepada korporasi besar yang terbukti melakukan pembakaran lahan atau perusahaanperusahaan besar yang terdeteksi dan tercatat ada titik api dan mengalami kebakaran tiap tahun di wilayah konsesinya.

Ketiga, Penegakan Hukum. Pemberian sanksi kepada pelaku pembakar lahan/hutan sesuai ketentuan peraturan perundang-undangan. Pasal 108 UU No. 32 Tahun 2009 tentang Perlindungan dan Pengelolaan Lingkungan Hidup sanksinya berupa pidana penjara paling singkat 3 tahun dan paling tinggi 10 tahun penjara, serta denda 3 milliar dan paling tinggi 10 milliar. Ketentuan ini sama dengan Pasal 108 UU No. 39 Tahun 2014 tentang Perkebunan.

Keempat, Sesuai amanat dari Pasal 7 AATHP. Indonesia harus segera membentuk atau menunjuk satu badan khusus sebagai Pusat Pemantauan Nasional yang memiliki tugas: Memantau daerah yang rawan kebakaran; Memantau kebakaran lahan dan hutan; Memantau kondisi lingkungan yang mengakibatkan kebakaran lahan/hutan; Memantau pencemaran asap yang ditimbulkan oleh kebakaran lahan/hutan.

Kelima, Berkomunikasi dengan ASEAN Centre (sebagai pusat koordinasi antara Para Pihak Perjanjian dalam mengelola dampak dari kebakaran lahan/hutan) terkait data sesuai dengan tugasnya.
Keenam, Sesuai amanat Pasal 9 AATHP, sebagai upaya pencegahan Indonesia wajib mempromosikan pendidikan dan kampanye pembangunan kesadaran masyarakat, misalnya melalui Focus Group Discussion (FGD) ataupun diseminasi serta memperkuat peran serta masyarakat dalam pengelolaan kebakaran guna mencegah kebakaran lahan dan hutan serta pencemaran asap yang timbul dari kebakaran tersebut.

\section{PENUTUP \\ Kesimpulan}

Pasca ratifikasi AATHP Indonesia memiliki kewajiban sebagai konsekuensi hukum atas keterikatannya dalam perjanjian tersebut, diantaranya sebagai berikut: a. Indonesia harus menjamin bahwa semua kegiatan yang ada wilayahnya tidak akan menyebabkan kerusakan lingkungan dan membahayakan kesehatan manusia bagi negara lain atau daerah di luar batas yurisdiksi nasionalnya; $b$. Indonesia wajib bekerjasama dalam mengembangkan dan melaksanakan tindakan untuk mencegah dan memantau pencemaran asap lintas batas akibat kebakaran lahan dan hutan; c. Indonesia wajib memberikan respon/tanggapan yang cepat terhadap adanya permintaan infomasi yang relevan atau konsultasi yang dibutuhkan oleh negara-negara yang terkena dampak pencemaran asap yang berasal dari Indonesia, dengan tujuan untuk meminimalkan dampak pencemaran; d. Indonesia wajib mengambil tindakan legislatif, administratif maupun tindakan lainnya sebagai upaya pencegahan dan pengendalian kebakaran hutan dan lahan yang berpotensi menimbulkan pencemaran asap lintas batas.

Disamping itu, Indonesia juga akan mendapatkan banyak keuntungan dengan meratifikasi AATHP, yaitu: a. Indonesia dapat memanfaatkan sumber daya manusia dan dana yang disediakan dalam kesepakatan ini. Pencemaran udara lintas batas dianggap sebagai masalah bersama oleh para anggota ASEAN. Bagi Indonesia tentunya menguntungkan mengingat keterbatasan dan ketidakmampuan untuk menyelesaikan sendiri; b. Dari sisi pertanggungjawaban negara atau liability, Indonesia akan terhindar dari potensi dimintai ganti rugi oleh negara tetangga; $\mathrm{c}$. Melihat kondisi asap yang berasal dari Indonesia maka ratifiaksi akan menguntungkan karena negara ASEAN yang dari tahun ke tahun mengalami masalah asap adalah Indonesia. Bila tidak terkena dampak, baru akan rugi karena dana dan 
berbagai sumber tidak bermanfaat bagi kepentingan nasional namun karena adanya solidaritas ASEAN saja; d. Indonesia akan memiliki anggaran yang terkumpul dari berbagai sumber yang dapat digunakan untuk mengatasi kebakaran hutan. Tanpa meratifikasi pun kita juga akan mengeluarkan dana untuk memadamkan kebakaran, namun dengan meratifikasi maka dana yang bisa digunakan akan menjadi lebih besar. Dengan AATHP, pengendalian kebakaran dapat dilaksanakan secara bersama-sama dengan negara ASEAN lainnya. Indonesia diuntungkan juga karena akan menjadi tuan rumah bagi adanya pertemuan ASEAN tentang perjanjian tersebut serta menjadi pusat kegiatan untuk penanggulangan polusi asap di ASEAN.

\section{Rekomendasi}

Adapun langkah-langkah yang harus dilakukan oleh Pemerintah Indonesia sebagai wujud itikad baik (good faith) dalam pelaksanaan ketentuan AATHP untuk mencegah dan mengendalikan kebarakan lahan dan hutan agar tidak menimbulkan pencemaran udara lintas batas yaitu:

Pertama, Bidang Legislatif. Perlunya revisi terhadap UU No. 32 Tahun 2009 tentang Perlindungan dan Pengelolaan Lingkungan Hidup dan UU No. 41 Tahun 1999 tentang Kehutanan karena dua undang-undang tersebut masih mentolerir perbuatan pembakaran lahan dan hutan. Ketentuan tersebut tentu saja bertentangan dengan isi dalam AATHP.

Kedua, Bidang Administratif. Pemberian ijin terhadap individu maupun korporasi untuk membuka/ menguasai lahan perlu untuk ditinjau ulang. Dalam era saat ini, pembangunan di setiap negara harus berlandaskan prinsip berkelanjutan atau sustainable development dengan mengedepankan tiga pilar yaitu pilar lingkungan hidup, pilar ekonomi dan pilar sosial. Jadi tidak tepat jika pertimbangan dalam pemberian ijin membuka/penguasaan lahan hanya demi keuntungan ekonomi semata. Pencabutan ijin terutama kepada korporasi besar yang terbukti melakukan pembakaran lahan atau perusahaanperusahaan besar yang terdeteksi dan tercatat ada titik api dan mengalami kebakaran tiap tahun di wilayah konsesinya.

Ketiga, Penegakan Hukum. Pemberian sanksi kepada pelaku pembakar lahan/hutan sesuai ketentuan peraturan perundang-undangan. Pasal 108 UU No. 32 Tahun 2009 tentang Perlindungan dan Pengelolaan
Lingkungan Hidup sanksinya berupa pidana penjara paling singkat 3 tahun dan paling tinggi 10 tahun penjara, serta denda 3 milliar dan paling tinggi 10 milliar. Ketentuan ini sama dengan Pasal 108 UU No. 39 Tahun 2014 tentang Perkebunan.

Keempat, Sesuai amanat Pasal 7 AATHP, Indonesia harus segera membentuk atau menunjuk satu badan khusus sebagai Pusat Pemantauan Nasional yang memiliki tugas: 1) Memantau daerah yang rawan kebakaran; 2) Memantau kebakaran lahan dan hutan; 3) Memantau kondisi lingkungan yang mengakibatkan kebakaran lahan/hutan; 4) Memantau pencemaran asap yang ditimbulkan oleh kebakaran lahan/hutan; 5) Berkomunikasi dengan ASEAN Centre (sebagai pusat koordinasi antara Para Pihak Perjanjian dalam mengelola dampak dari kebakaran lahan/hutan) terkait data sesuai dengan tugasnya.

Kelima, Sesuai amanat Pasal 9 AATHP, sebagai upaya pencegahan Indonesia wajib mempromosikan pendidikan dan kampanye pembangunan kesadaran masyarakat, misalnya melalui Focus Group Discussion (FGD) ataupun diseminasi serta memperkuat peran serta masyarakat dalam pengelolaan kebakaran guna mencegah kebakaran lahan dan hutan serta pencemaran asap yang timbul dari kebakaran tersebut.

\section{DAFTAR PUSTAKA}

\section{Peraturan Perundang-undangan:}

Undang-Undang Nomor 32 Tahun 2009 tentang Perlindungan dan Pengelolaan Lingkungan Hidup.

Undang-Undang Nomor 41 Tahun 1999 tentang Kehutanan.

\section{Buku:}

Klabbers, Jan, 1998, The Concept of Treaty In International Law Vol. 22, Netherlands: Kluwer Law International, Dordrecht.

Linderfalk, Ulf, 2007, On the Interpretation of Treaties: The Modern International Law as Expressed in the 1969 Vienna Convention on the Law of Treaties, Netherlands: Springer, Dordrecht.

Parthiana, I Wayan, 2002, Hukum Perjanjian Internasional Bagian 1, Bandung: Mandar Maju.

Pratomo, Eddy, 2012, Hukum Perjanjian Internasional: Pengertian, Status Hukum, dan Ratifikasi, Bandung: Alumni. 


\section{Perjanjian Internasional:}

ASEAN Agreement on Transboundary Haze Pollution 2002.

\section{Makalah:}

Ahmadi, Sidiq, 2013, "Prinsip Non-Interference ASEAN dan Problem Efektifitas ASEAN Agreement On Transboundary Haze Pollution", Jurnal Media Hukum, Universitas Muhammadiyah Yogyakarta.

\section{Website:}

Badan Nasional Penanggulangan Bencana, Data Sebaran Titik Panas Nusantara rentang bulan Januari-Oktober 2014, http://geospasial.bnpb. go.id/monitoring/hotspot/

Anonim, Indonesia Siap Ratifikasi Perjanjian Asap, http://www.tempo.co/read/news/2013/07/ 18/118497386/Indonesia-Siap-RatifikasiPerjanjian-Asap 